\title{
Employee Engagement Strategies in Software Companies in Chennai
}

\author{
Keerthana Y. H., T. K. Avvai Kothai
}

\begin{abstract}
The level of enthusiasm an employee feels towards the job is called as Employee Engagement. An engaged employee cares about his performance and its effect on the organization. It is an internal state of mind that binds together work force, commitment and satisfaction in an employee. The organization has to look after its employees so that they can satisfy their customers. The management has to find out what the employees want so that the ultimate goal of organization is achieved. Strategies like Transparency, Empowerment, Purpose, Behaviour and Listening can be used to engage the employees. This study mainly focuses on the engagement strategies applied in selected software companies in Chennai and also aims to explore the strategies that drive employee engagement in software companies. This empirical paper also seeks to find the effect of the identified strategies on employee engagement.
\end{abstract}

Keywords: Employee Engagement, Organizational Performance and Strategies.

\section{INTRODUCTION}

$\mathbf{E}_{\text {mployees are the most useful and beneficial resources }}$ in every industry. It is very difficult to make work interesting for employees in an organization as they might feel that they are doing the same work over and again. This is where motivation, training and engagement play an important part. Employee Engagement is the level of enthusiasm and dedication an employee feels towards his or her job. The employee uses his or her talents and improves the outcome and develops productive relationship. Engaged employees help to improve the performance of the organization in several ways such as Profitability, Productivity, Customer satisfaction, Innovation and Absenteeism. Engaged employees care about their performance and its effect on the organization as they feel that their effort could make difference. It is an internal state of mind that binds together work effort, commitment and satisfaction in an employee. It is the eagerness towards the task that motivates them to do the work and is often reflected in the outcome. An engaged employee is enthusiastic about the work place and takes positive action to increase organization's reputation. It is the work of the employer to make sure that his employee is impressed about the work place like the goals or targets to be achieved, environment, organization culture and also has to

Revised Manuscript Received on December 05, 2019.

* Correspondence Author

Keerthana Y.H.*, Research Scholar, P.G and Research Department of Commerce. Guru Nanak College (Autonomous), Chennai, India. Email: kinku.rashu@gamil.com

Dr. T.K. Avvai Kothai, Associate Professor, P.G and Research Department of Commerce. Guru Nanak College (Autonomous), Chennai, India. ensure that his employees are comfortable with the organization. Employee engagement occurs when the goals of the organization are aligned with the goals of the employee. Earlier employees were interested only in the task given to them and not in the business. As the competition grew the employers learnt that it was essential to engage the employees and make them feel as the integral part of the business to increase their growth. In 2017, as per the Gallup's State of the Global Workplace report, it was found that only $15 \%$ of the employees around the world are engaged in their job, meaning that they are emotionally interested in the job i.e. they are contributing their time, talent and ideas for the organization's growth. The main aim of engagement is to achieve the ultimate goal of organization i.e. customer satisfaction. If the employees find their job interesting and are engaged in it they achieve the ultimate goal i.e. customer satisfaction.

\section{a. Strategies}

In order to engage the employees the Organization or employer may follow the following strategies:

- Transparency: Transparency is sharing of information among all in the organization. It helps openness between the employer and employee. It is nothing but an idea to break down the barriers, encourage creativity and collaboration among employees. The employees may be asked to be transparent in the work place by sharing the feedback or suggestions about their employers, peer groups etc.

- Empowerment: Empowerment is where the employees are given authority to make decisions regarding training, hiring, pay scales, priorities, schedules etc. In simple terms it means giving employees authority to make or take decisions regarding their job. Authority is given to the employee to make him feel that he is given importance in the organization. When an employee is empowered he will be loyal to the organization, will be motivated to work more, will perform well which ultimately benefits both the employer as well as the employee

- Purpose: The purpose of employee engagement is to make the employees committed to their job. Employees feel engaged when they are able to understand the true nature of the job or work given to them, when they feel comfortable with the organizational culture and when they are given proper guidance. Apart from the pay benefits they receive, the employees expect all these to keep themselves committed and engaged in the job.

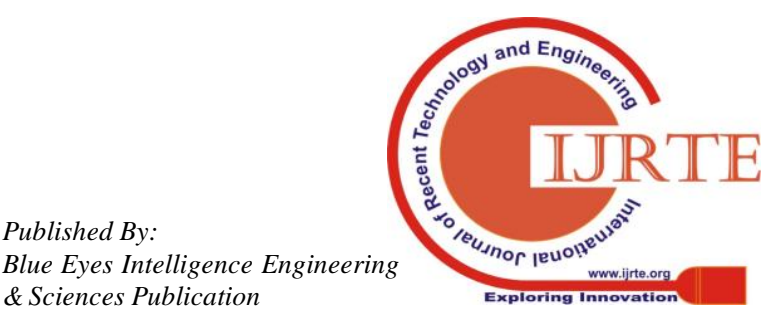




\section{Employee Engagement Strategies in Software Companies in Chennai}

Not only the organization's reputation but the work environment also influences the engagement. However there won't be loyalty when an employee isn't engaged in his job. The engagement activities should benefit both the employer as well as employee. It should create interest for the employee to do his job. A strong, clear purpose should be conveyed to the employees properly through the engagement activities. The engagement should make the employees feel connected to their job, which should make the employees change the perception of their job, mostly to a positive perception.

- Behaviour: Behaviours are how a person conducts oneself, acts or reacts towards others or a situation. Behaviour impacts employee on an emotional level and has a great impact on engagement. Not only the behavior of the employer, but also the behaviours of the peer group or co workers also make an employee lose interest in the job. It is in the hands of the employer to make sure that the differences within the organization are solved soon.

- Listening: The employer must develop the habit of listening to his employees. The more they listen to their employees, the more they get new ideas, feedbacks, and they also receive employees opinions on certain issues which might be more useful to the organization. It will be a win-win situation for both the organization as well as employees. The employees might feel that organization is giving them importance by listening to them, and the employer by listening gets more new ideas, come to know about the flaws in the organization and also gets to know the employees well.

- Rewards and Recognition: Generally it is assumed that rewards and recognition are given to employees to motivate them. The employees get something in return for the work done by them, and they also believe that when they get rewards their work is meaningful and engage themselves more in their work (Macey and Schneider, 2008). Recognition is the key driver for employees. The organization has to understand individual's need for reward and fulfill them in order to engage them continuously.

- Training: The organization takes care of its employees through training. Employees receiving benefits through training, incentives and resources from the organization are likely to be motivated and engaged in the organization. Employee motivation is enhanced through training which leads to best organizational performance.

\section{OBJECTIVES OF THE STUDY}

- To explore the strategies that drive employee engagement in software companies.

- To find the effect of identified strategies on employee engagement.

- To see the influence of demographic factors on employee engagement.

\section{a. Limitations}

- The study has been limited to selected software companies in Chennai city.

- The sample size has been limited to 51 due to time constraint.

\section{RESEARCH METHODOLOGY}

The area of study is Software companies in Chennai City. The Sample Size is 50 and the sampling technique used in this study is Convenience Sampling. The population targeted here is employees of software companies and primary data was collected using questionnaire. Secondary data was also collected referring to journals and websites.

\section{ANALYSIS AND INTERPRETATION}

Statistical tools like ANOVA, Factor Analysis and Correlation are used through SPSS software.

Table1.1: Significance of difference among Income group in Empowerment factors

\begin{tabular}{|c|c|c|c|c|c|}
\hline & $\begin{array}{l}\text { Income } \\
\text { Group }\end{array}$ & $\begin{array}{l}\text { Mean } \\
(\mathrm{SD})\end{array}$ & $\begin{array}{c}\mathrm{F} \\
\text { value } \\
(\mathrm{Df}= \\
47)\end{array}$ & $\begin{array}{c}\mathrm{P} \\
\text { value }\end{array}$ & Inference \\
\hline \multirow{5}{*}{$\begin{array}{l}\text { Quality of Work } \\
\text { Life } \\
\text { Factor(QWLF) }\end{array}$} & $<$ Rs 25000 & $\begin{array}{l}28.07 \\
(4.55) \\
\end{array}$ & \multirow{5}{*}{3.198} & \multirow{5}{*}{0.032} & \multirow{5}{*}{ Significant } \\
\hline & $\begin{array}{c}\text { Rs } 25000-\text { Rs } \\
50000\end{array}$ & $\begin{array}{l}27.64 \\
(3.81)\end{array}$ & & & \\
\hline & $\begin{array}{c}\text { Rs } 50000-\text { Rs } \\
75000\end{array}$ & $\begin{array}{l}22.45 \\
(7.26)\end{array}$ & & & \\
\hline & > Rs 75000 & $\begin{array}{l}27.75 \\
(6.18) \\
\end{array}$ & & & \\
\hline & Total & $\begin{array}{l}26.65 \\
(5.41) \\
\end{array}$ & & & \\
\hline \multirow{5}{*}{$\begin{array}{c}\text { Employee } \\
\text { Encouragement } \\
\text { Factor (EEF) }\end{array}$} & $<$ Rs 25000 & $\begin{array}{l}12.21 \\
(1.67)\end{array}$ & \multirow{5}{*}{1.026} & \multirow{5}{*}{0.390} & \multirow{5}{*}{$\begin{array}{c}\text { Not } \\
\text { Significan }\end{array}$} \\
\hline & $\begin{array}{c}\text { Rs } 25000-\text { Rs } \\
50000\end{array}$ & $\begin{array}{l}11.86 \\
(2.14) \\
\end{array}$ & & & \\
\hline & $\begin{array}{c}\text { Rs } 50000-\mathrm{Rs} \\
75000\end{array}$ & $\begin{array}{l}10.82 \\
(2.56) \\
\end{array}$ & & & \\
\hline & > Rs 75000 & $\begin{array}{l}12.25 \\
(2.06) \\
\end{array}$ & & & \\
\hline & Total & $\begin{array}{l}11.76 \\
(2.12)\end{array}$ & & & \\
\hline
\end{tabular}

(i)Quality of Work Life Factor:

Null Hypothesis $\left(\mathbf{h}_{\mathbf{0}}\right)$ : There is a significant difference among the quality of work life factor and income group.

Alternate Hypothesis $\left(\mathbf{h}_{1}\right)$ : There is no significance difference among the quality of work life factor and income group.

Interpretation: There is a significant difference among the quality of work life factor and income group as the null hypothesis has been accepted at 5\% significant level [ $\mathrm{F}$ 3.198,Df 47 and P 0.032]

\section{(ii)Employee Encouragement Factor:}

Null Hypothesis $\left(\mathbf{h}_{\mathbf{0}}\right)$ : There is a significant difference among employee encouragement factor and income group.

Alternate Hypothesis $\left(\mathbf{h}_{\mathbf{1}}\right)$ : There is no significance difference among the employee encouragement factor and income group.

Interpretation: There is no significant difference among the employee encouragement factor and income group as the null hypothesis has been rejected at 5\% significant level [ $\mathrm{F}$ 1.026, Df 47, P 0.390]. 
Table 1.2: Significance of difference among Income group and Overall Transparency

\begin{tabular}{|c|c|c|c|c|c|}
\hline & $\begin{array}{l}\text { Income } \\
\text { Group }\end{array}$ & $\begin{array}{c}\text { Mean } \\
\text { (SD) }\end{array}$ & $\begin{array}{c}\text { F Value } \\
(\mathrm{Df}= \\
47)\end{array}$ & P Value & Inference \\
\hline \multirow{5}{*}{ Over all Transparency } & $<$ Rs 25000 & $\begin{array}{l}27.00 \\
(4.00)\end{array}$ & \multirow{5}{*}{1.472} & \multirow{5}{*}{0.234} & \multirow{5}{*}{$\begin{array}{c}\text { Not } \\
\text { Significant }\end{array}$} \\
\hline & $\begin{array}{l}\text { Rs } 25000- \\
\text { Rs } 50000\end{array}$ & $\begin{array}{l}27.73 \\
(4.29)\end{array}$ & & & \\
\hline & $\begin{array}{l}\text { Rs } 50000- \\
\text { Rs } 75000\end{array}$ & $\begin{array}{l}24.00 \\
(6.46)\end{array}$ & & & \\
\hline & $>$ Rs 75000 & $\begin{array}{l}27.25 \\
(6.18)\end{array}$ & & & \\
\hline & Total & $\begin{array}{l}26.69 \\
(4.96)\end{array}$ & & & \\
\hline
\end{tabular}

Null Hypothesis $\left(\mathbf{h}_{\mathbf{0}}\right)$ : There is a significant difference among income group in overall transparency

Alternate Hypothesis $\left(\mathbf{h}_{1}\right)$ : There is no significant difference among income group in overall transparency.

Interpretation: There is no significant difference among income group in overall transparency as null hypothesis has been rejected at 5\% significant level [ F 1.472, D.f 47 and P $0.234]$.

Table 1.3: Significance of Age group with Rewards and Recognition

\begin{tabular}{|c|c|c|c|c|c|}
\hline & Age Group & $\begin{array}{l}\text { Mean } \\
\text { (SD) }\end{array}$ & $\begin{array}{c}\text { F Value }(\mathrm{Df}= \\
48)\end{array}$ & P Value & Inference \\
\hline \multirow{4}{*}{$\begin{array}{c}\text { Financial } \\
\text { Benefits } \\
\text { Factor }\end{array}$} & $<25$ & $\begin{array}{l}26.53 \\
(4.24) \\
\end{array}$ & \multirow{4}{*}{2.647} & \multirow{4}{*}{0.81} & \multirow{4}{*}{ Not Significant } \\
\hline & $25-35$ & $\begin{array}{l}23.76 \\
(6.97) \\
\end{array}$ & & & \\
\hline & $36-45$ & $\begin{array}{l}16.00 \\
(12.73)\end{array}$ & & & \\
\hline & Total & $\begin{array}{l}24.27 \\
(6.69)\end{array}$ & & & \\
\hline \multirow{4}{*}{$\begin{array}{l}\text { Inducive } \\
\text { Factor }\end{array}$} & $<25$ & $\begin{array}{c}7.33 \\
(1.54) \\
\end{array}$ & \multirow{4}{*}{1.315} & \multirow{4}{*}{0.278} & \multirow{4}{*}{ Not Significant } \\
\hline & $25-35$ & $\begin{array}{l}6.76 \\
(2.61) \\
\end{array}$ & & & \\
\hline & $36-45$ & $\begin{array}{c}4.50 \\
(3.53)\end{array}$ & & & \\
\hline & Total & $\begin{array}{l}6.84 \\
(2.39)\end{array}$ & & & \\
\hline
\end{tabular}

(i)Financial Benefits Factor:

Null Hypothesis $\left(\mathbf{h}_{\mathbf{0}}\right)$ : There is a significant difference among financial benefits factor and age.

Alternate Hypothesis $\left(\mathbf{h}_{\mathbf{1}}\right)$ : There is no significant difference among financial benefit factor age.

Interpretation: The is no significant difference among the financial benefits factor and the age group as the null hypothesis is rejected at 5\% significant level [ F 2.647, D.f 48 and $P$ 0.81].

\section{(ii)Inducive Facotor:}

Null Hypothesis $\left(\mathbf{h}_{0}\right)$ : There is a significant difference among inducive factor and age.

Alternate Hypothesis $\left(\mathbf{h}_{\mathbf{1}}\right)$ : There is no significant difference among inducive factor age.

Interpretation: There is no significant difference among the inductive factor and age group as the null hypothesis has been rejected at 5\% significant level [ F 1.315, D.f 48 and P $0.278]$.

Table 1.4: Significance of Income group with Purpose factor

\begin{tabular}{|c|c|c|c|c|c|}
\hline & Income Group & $\begin{array}{c}\text { Mean } \\
(\mathrm{SD})\end{array}$ & $\begin{array}{l}\text { F Value } \\
(\mathrm{Df}=47)\end{array}$ & P Value & Inference \\
\hline \multirow{5}{*}{$\begin{array}{l}\text { Resources } \\
\text { Factor }\end{array}$} & $<\operatorname{Rs} 25000$ & $\begin{array}{l}11.78 \\
(1.58)\end{array}$ & \multirow{5}{*}{0.710} & \multirow{5}{*}{0.551} & \multirow{5}{*}{ Not Significant } \\
\hline & $\begin{array}{l}\text { Rs } 25000- \\
\text { Rs } 50000\end{array}$ & $\begin{array}{l}11.64 \\
(2.08) \\
\end{array}$ & & & \\
\hline & $\begin{array}{l}\text { Rs 50000- } \\
\text { Rs 75000 }\end{array}$ & $\begin{array}{l}10.81 \\
(3.16)\end{array}$ & & & \\
\hline & > Rs 75000 & $\begin{array}{l}10.25 \\
(4.03) \\
\end{array}$ & & & \\
\hline & Total & $\begin{array}{l}11.39 \\
(2.38) \\
\end{array}$ & & & \\
\hline \multirow{5}{*}{$\begin{array}{l}\text { Ambience } \\
\text { Factor }\end{array}$} & $<$ Rs 25000 & $\begin{array}{l}12.21 \\
(1.42)\end{array}$ & \multirow{5}{*}{2.177} & \multirow{5}{*}{0.103} & \multirow{5}{*}{ Not Significant } \\
\hline & $\begin{array}{l}\text { Rs } 25000- \\
\text { Rs } 50000\end{array}$ & $\begin{array}{l}12.27 \\
(1.91) \\
\end{array}$ & & & \\
\hline & $\begin{array}{l}\text { Rs 50000- } \\
\text { Rs 75000 }\end{array}$ & $\begin{array}{l}10.36 \\
(3.11) \\
\end{array}$ & & & \\
\hline & > Rs 75000 & $\begin{array}{l}11.75 \\
(2.36) \\
\end{array}$ & & & \\
\hline & Total & $\begin{array}{l}11.80 \\
(2.22)\end{array}$ & & & \\
\hline
\end{tabular}

(i)Resources Factor:

Null Hypothesis $\left(\mathbf{h}_{\mathbf{0}}\right)$ : There is significant difference among the resource factor and income group.

Alternate Hypothesis $\left(\mathbf{h}_{\mathbf{1}}\right)$ : There is no significant difference among the resource factor and income group.

Interpretation: There is no significant difference among the resource factor and the income group as the null hypothesis has been rejected at 5\% significance level [ F 0.710. D.f 47 and $\mathrm{P}$ 0.551].

\section{(ii)Ambience Factor:}

Null Hypothesis $\left(\mathbf{h}_{\mathbf{0}}\right)$ : There is significant difference among ambience factor and income group.

Alternate Hypothesis $\left(\mathbf{h}_{\mathbf{1}}\right)$ : There is no significant difference among ambience factor and income group.

Interpretation: There is no significant difference among ambience factor and income group as the null hypothesis has been rejected at $5 \%$ significance level [ F 2.177, D.f 47 and P $0.103]$. 
Table 2.1: Factorization of Empowerment Variables

\begin{tabular}{|c|c|c|c|c|c|c|}
\hline Variables & $\begin{array}{l}\text { Factor } \\
\text { Loadings }\end{array}$ & Mean & $\begin{array}{c}\text { Std. } \\
\text { deviation }\end{array}$ & Communalities & MSA & Factor Name \\
\hline Equipments to complete the work assigned & 0.848 & 4.06 & .810 & 0.746 & 0.861 & \multirow{7}{*}{$\begin{array}{l}\text { Quality of Work } \\
\text { Life }\end{array}$} \\
\hline Sufficient free time & 0.844 & 3.75 & 1.017 & 0.758 & 0.857 & \\
\hline Freedom in performing & 0.835 & 4.08 & 0.997 & 0.705 & 0.802 & \\
\hline Alternate work schedule & 0.752 & 3.86 & 1.059 & 0.597 & 0.856 & \\
\hline Opportunity to develop special ability & 0.713 & 3.61 & 0.981 & 0.644 & 0.884 & \\
\hline Tolerated mistakes and failures & 0.65 & 3.67 & 1.031 & 0.479 & 0.922 & \\
\hline Encourages participative decision making & 0.605 & 3.63 & 0.937 & 0.687 & 0.875 & \\
\hline Challenging Work & 0.909 & 4.12 & 0.739 & 0.826 & 0.628 & \multirow{2}{*}{$\begin{array}{c}\text { Employee } \\
\text { Encouragement }\end{array}$} \\
\hline Work Culture & 0.761 & 4.04 & 0.824 & 0.677 & 0.803 & \\
\hline
\end{tabular}

KMO and Bartlett's test of sphericity: 0.843, Chi-square : 331.455, P value: 0.000 and Variance Explained: 69.347

Interpretation: Factor Analysis has been applied to determine latent dominant dimensions of 10 employee empowerment variables. The Mean values are lower than their Standard Deviation. Communality values are ranging between 0.826 and 0.479 , where as MSA values are ranging between 0.922 and 0.628. KMO and Bartletts's test of sphericity 0.843 , Chi square value of 331.455 , with degree of freedom of 45 and $\mathrm{P}$ Value of 0.000 indicates that factor analysis can be applied to 10 employee empowerment variables.
Two Factor Analysis has been extracted out of 10 Employee Empowerment Factors. The most dominant factor 1 namely Quality of work life explains $56.53 \%$ of variance includes 7 variables of Employee Empowerment factor. The second most dominant factor namely Employee Encouragement Factor explains $24.367 \%$ of variance in Employee Empowerment Factor including 3 variables of Employee Empowerment factor.

Table 2.2: Factorization of Purpose Variables

\begin{tabular}{|c|c|c|c|c|c|c|}
\hline Variables & $\begin{array}{l}\text { Factor } \\
\text { Loadings }\end{array}$ & Mean & $\begin{array}{c}\text { Std. } \\
\text { Deviation }\end{array}$ & Communalities & MSA & $\begin{array}{l}\text { Factor } \\
\text { Name }\end{array}$ \\
\hline Resources are Adequate & 0.740 & 3.82 & 0.767 & 0.805 & 0.843 & \multirow{3}{*}{$\begin{array}{c}\text { Resource } \\
\text { Factor }\end{array}$} \\
\hline Technology provided is adequate & 0.846 & 3.88 & 0.816 & 0.810 & 0.869 & \\
\hline Right to put suggestions and opinions & 0.865 & 3.69 & 1.068 & 0.817 & 0.902 & \\
\hline Work environment is conducive & 0.732 & 3.94 & 0.810 & 0.857 & 0.826 & \multirow{2}{*}{$\begin{array}{c}\text { Ámbience } \\
\text { Factor }\end{array}$} \\
\hline Great place to work & 0.638 & 3.82 & 0.953 & 0.635 & 0.877 & \\
\hline
\end{tabular}

KMO and Bartlett's test of sphericity: 0.864, Chi-square : 198.792, P Value: 0.000 and Variance explained : 79.852

Interpretation: Factor Analysis has been applied to determine latent dominant dimensions of 6 employee purpose variables. The Mean values are lower than their Standard Deviation. Communality values are ranging between 0.867 and 0.653 , where as MSA values are ranging between 0.902 and 0.826 . KMO and Bartletts's test of sphericity 0.864 , Chi square value of 198.792 , with degree of freedom of 15 and $\mathrm{P}$ Value of 0.000 indicates that factor analysis can be applied to 6 employee purpose variables.

Two Factor Analysis has been extracted out of 6 Employee Purpose Factors. The most dominant factor 1 namely Resource Factor explains $69.586 \%$ of variance includes 3 variables of Employee Purpose factor. The second most dominant factor namely Ambience Factor explains 24.367\% of variance in Employee Purpose Factor including 3 variables of Employee Purpose factor. 
Table 2.3: Factorization of Rewards and Recognition Variables

\begin{tabular}{|c|c|c|c|c|c|c|}
\hline Variables & $\begin{array}{l}\text { Factor } \\
\text { Loadings }\end{array}$ & Mean & Std. Deviation & Communalities & MSA & Factor Name \\
\hline Salary is fair and adequate & 0.797 & 3.57 & 1.005 & 0.733 & 0.928 & \multirow{7}{*}{$\begin{array}{l}\text { Financial } \\
\text { Benefits }\end{array}$} \\
\hline Superior- subordinate relations are cordial & 0.843 & 3.37 & 1.113 & 0.836 & 0.911 & \\
\hline Performance is rewarded & 0.834 & 3.45 & 1.154 & 0.839 & 0.905 & \\
\hline Rewards encourage innovations & 0.887 & 3.51 & 1.065 & 0.866 & 0.882 & \\
\hline Yearly increments are given & 0.647 & 3.37 & 1.131 & 0.762 & 0.936 & \\
\hline Performance is appreciated & 0.726 & 3.55 & 1.045 & 0.769 & 0.859 & \\
\hline Birthday greetings are received & 0.653 & 3.45 & 1.064 & 0.751 & 0.902 & \\
\hline Benefits and allowances are given without interruption & 0.686 & 3.39 & 1.185 & 0.849 & 0.898 & \multirow{2}{*}{$\begin{array}{l}\text { Inducive } \\
\text { Factor }\end{array}$} \\
\hline Achievements are published & 0.924 & 3.45 & 1.376 & 0.908 & 0.855 & \\
\hline
\end{tabular}

Interpretation: Factor Analysis has been applied to determine latent dominant dimensions of 9 employee rewards and recognition variable. The Mean values are lower than their Standard Deviation. Communality values are ranging between 0.908 and 0.733 , where as MSA values are ranging between 0.928 and 0.855 , KMO and Bartletts's test of sphericity 0.898 , Chi square value of 445.656 , with degree of freedom of 36 and $\mathrm{P}$ Value of 0.000 indicates that factor analysis can be applied to 9 employee rewards and recognition variables.

Two Factor Analysis has been extracted out of 9 Employee Rewards and Recognition Factors. The most dominant factor 1 namely Financial Benefits Factor explains $74.435 \%$ of variance includes 7 variables of Financial Benefits factor. The second most dominant factor namely Inducive Factor explains $29.951 \%$ of variance in Employee Purpose Factor including 2 variables of Inducive factor.

Table 3.1:Relationship between Transparency and other dependant variables

\begin{tabular}{|c|c|c|c|c|c|c|c|c|}
\hline & & x7.total & x8.total & x9.total & $\mathrm{x}$ 10.total & $\mathrm{x} 11$.total & $\mathrm{x} 12$. total & $\mathrm{x}$ 13.total \\
\hline \multirow{3}{*}{$\mathrm{x} 7$. total } & Pearson Correlation & 1 & $.755^{* * *}$ & $.794 * *$ & $.645^{* *}$ & $.743 * *$ & $.749 * *$ & $.774 * *$ \\
\hline & Sig. (2-tailed) & & .000 & .000 & .000 & .000 & .000 & .000 \\
\hline & $\mathrm{N}$ & 51 & 51 & 51 & 51 & 51 & 51 & 51 \\
\hline \multirow{2}{*}{ x8.total } & Pearson Correlation & $.755 * *$ & 1 & $.779 * *$ & $.599 * *$ & $.746 * *$ & $.629 * *$ & $.753 * *$ \\
\hline & $\mathrm{N}$ & 51 & 51 & 51 & 51 & 51 & 51 & 51 \\
\hline \multirow{3}{*}{ x9.total } & Pearson Correlation & $.794 * *$ & $.779 * *$ & 1 & $.642 * *$ & $.826^{* * *}$ & $.816^{* * *}$ & $.751 * *$ \\
\hline & Sig. (2-tailed) & .000 & .000 & & .000 & .000 & .000 & .000 \\
\hline & $\mathrm{N}$ & 51 & 51 & 51 & 51 & 51 & 51 & 51 \\
\hline \multirow{3}{*}{ x10.total } & Pearson Correlation & $.645 * *$ & $.599 * *$ & $.642 * *$ & 1 & $.722 * *$ & $.599 * *$ & $.544 * *$ \\
\hline & Sig. (2-tailed) & .000 & .000 & .000 & & .000 & .000 & .000 \\
\hline & $\mathrm{N}$ & 51 & 51 & 51 & 51 & 51 & 51 & 51 \\
\hline \multirow{3}{*}{$\mathrm{x} 11$.total } & Pearson Correlation & $.743 * *$ & $.746 * *$ & $.826 * *$ & $.722 * *$ & 1 & $.769 * *$ & $.759 * *$ \\
\hline & Sig. (2-tailed) & .000 & .000 & .000 & .000 & & .000 & .000 \\
\hline & $\mathrm{N}$ & 51 & 51 & 51 & 51 & 51 & 51 & 51 \\
\hline \multirow{3}{*}{$\mathrm{x}$ 12.total } & Pearson Correlation & $.749 * *$ & $.629 * *$ & $.816^{* *}$ & $.599 * *$ & $.769 * *$ & 1 & $.840^{* * *}$ \\
\hline & Sig. (2-tailed) & .000 & .000 & .000 & .000 & .000 & & .000 \\
\hline & $\mathrm{N}$ & 51 & 51 & 51 & 51 & 51 & 51 & 51 \\
\hline \multirow{2}{*}{ x13.total } & Pearson Correlation & $.774 * *$ & $.753 * *$ & $.751 * *$ & $.544^{* *}$ & $.759 * *$ & $.840 * *$ & 1 \\
\hline & Sig. (2-tailed) & .000 & .000 & .000 & .000 & .000 & .000 & \\
\hline
\end{tabular}




\begin{tabular}{|l|l|l|l|l|l|l|l|l|}
\hline & $\mathrm{N}$ & 51 & 51 & 51 & 51 & 51 & 51 & 51 \\
\hline
\end{tabular}

\section{Interpretation:}

(a) There is significant correlation between overall transparency and employee empowerment as the Null hypothesis is rejected at $5 \%$ significance level [ $\mathrm{R} 0.755, \mathrm{P}$ $0.000]$.

(b) There is significant correlation between overall transparency and employee purpose as the Null hypothesis is rejected at 5\% significant level [R 0.794, P 0.000].

(c) There is significant correlation between overall transparency and employee behavior as the Null hypothesis is rejected at 5\% significant level [R 0.645, P 0.000].

(d) There is significant correlation between overall transparency and employee listening as the Null hypothesis is rejected at 5\% significant level [R 0.743, P 0.000].

(e) There is significant correlation between overall transparency and employee rewards and recognition as the Null hypothesis is rejected at 5\% significant level [R 0.0.749, P 0.000].

(f) There is significant correlation between overall transparency and employee purpose as the Null hypothesis is rejected at 5\% significant level [R 0.774, P 0.000].

\section{FINDINGS}

- With a total of 51 respondents, more than one- third of the respondents are aged between $25-35$ years. $72.5 \%$ of the respondents are Male. One-third of the respondents are Post Graduates and majority of the respondents are earning monthly income between Rs 25,000- Rs 50,000

- From the study it may be concluded that the identified strategies like Transparency, Empowerment, Purpose, Behaviour, Listening, Rewards and Recognition and Training have an impact on employee engagement.

- Demographic factors like Age, Gender, Educational Qualification and Monthly Income of the respondents also influence the employee engagement.

\section{CONCLUSION}

The emotional commitment that an employee has towards his job and employer which influences his behavior towards the organization and also work related activities is known as employee engagement. The organization apart from regular engagement activities can make the employees engaged in their job by taking small steps like listening to the employees, giving them authority to take certain decisions, giving them information as and when required and making the work environment friendly. It is not necessary that the organization has to spend more on engagement activities. Simple steps like listening, empowering, being transparent and correcting their behavior makes the employees believe that the organization is giving them importance which leads to engagement. By following these steps the organization can save cost and can also solve problems easily

\section{REFERENCES}

1. Kumar, X. J. L., \& Gopinath, T. (2016). An Empirical Study on Employee Engagement and Retention Strategies in BPO Companies in India. Bonfring International Journal of Industrial Engineering and Management Science, 6(2).

2. McManus, J., \& Mosca, J. (2015). Strategies to build trust and improve employee engagement. International Journal of Management \& Information Systems (IJMIS), 19(1).

3. https://decision-wise.com/7-definitions-of-employee-engagement/

4. https://www.cornerstoneondemand.com/resources/articles/why-empower ment-key-employee-engagement

5. https://www.managers.org.uk/insights/news/2015/december/six-companie s-that-get-employee-engagement-and-what-they-do-right

6. https://inside.6q.io/the-definition-of-employee-engagement/

7. https://www.floship.com/employee-engagement-strategies-2018/

8. https://engageforsuccess.org/what-is-employee-engagement

9. https://www.cmswire.com/cms/enterprise-collaboration/3-reasons-why-or ganizations-need-to-increase-transparency-011886.php

10. https://woman.thenest.com/meaning-transparency-workplace-12630.html

11. https://decision-wise.com/employee-empowerment-vs-employee-engagem ent/

12. https://trainingindustry.com/blog/performance-management/how-learning -development-impacts-employee-engagement/

13. https://marketbusinessnews.com/financial-glossary/organizational-perfor mance-definition-meaning/.

\section{AUTHORS PROFILE}

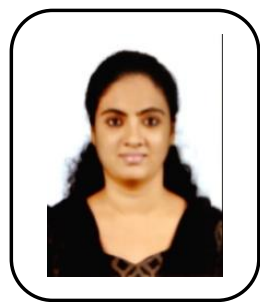

Ms. Keerthana. Y.H is a full time Ph.D. Research Scholar in Guru Nanak College [Autonomous] Chennai. Her field of research is Human Resource Management. She has completed her M.Com., in Ethiraj College for Women [Autonomous], Chennai She has worked as Assistant Professor in Dr .M.G.R Janaki College of Arts and Science for Women, Chennai.She is very active in presenting papers in seminars and conferences.

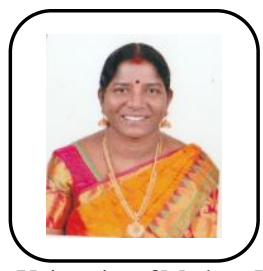

Dr. T. K. Avvai Kothai, Associate Professor \& Research Supervisor, PG \& Research Department of Commerce, Guru Nanak College [Autonomous], Chennai -42 . She has 32 years of collegiate teaching experience. She did her M.Com. in Ethiraj College for Women, Chennai, with a University Rank and further completed M.Phil.,and Ph.D. in University of Madras. She is recognized research supervisor of the University of Madras. Under her guidance, five candidates have completed their $\mathrm{PhDs}$ and currently five candidates are pursuing their research. She has presented \&published several research papers in national \& international conferences. She has received the 'Best Paper Award' for two of her research papers in international conference. She was recognized for her contributions in the field of Education and Research, with the 'Life Time Achievement Award' in December 2018, by D.K. International Research Foundation. In February 2019, she received the 'Achievement Award for Excellence in Teaching \& Research' from Grabs Educational Charitable Trust. She received the 'Life Time Achievement National Award' in August 2019 from the IRDP Group of Journals. 